\title{
Antimicrobial Susceptibility Profile from Patients with Blood Stream Infections at a Tertiary Care Level Super Speciality Institute in Northern India
}

\author{
Manodeep Sen, Vikramjeet Singh, Gaurav Kumar, Rachana Kanaujia, \\ Vineeta Mittal and Anupam Das*
}
Department of Microbiology, Dr Ram Manohar Lohia Institute of Medical Sciences, Lucknow, India

*Corresponding author

\begin{abstract}
A B S T R A C T
Globally, the frequency of bloodstream infections, their epidemiology, invading organisms $\&$ antimicrobial susceptibility pattern are always changing and giving rise to new resistance with every passing year. To study the frequency \& antimicrobial susceptibility pattern of bacterial pathogens causing bloodstream infections in patients attending tertiary

Keywords

Blood stream infections,

Antimicrobial

Susceptibility Profile

Article Info

Accepted:

20 May 2018

Available Online:

10 June 2018

care super speciality institute of Northern India. This was a retrospective clinicallaboratory based study carried over two year period from January 2015 to December 2016 at tertiary health care centre. Blood samples collected from clinically suspected cases of bacteraemia were processed through automated Versa Trek blood culture system. The samples yielding positive growth were further analysed to identify the pathogen \& their antimicrobial susceptibility. Overall blood culture positivity were $15.07 \%$ in 2015 \& $18.45 \%$ in 2016 . Gram positive bacteria predominated amongst the all bacterial isolates, of which Coagulase negative Staphylococcus were $37.69 \%$ in 2015 \& $38.73 \%$ in 2016.Amongst gram negative bacteria Escherichia coli was the major isolate being $11.57 \%$ in $2015 \& 13.02 \%$ in 2016 . Gram positive bacteria showed maximum resistant to Penicillin, while gram negative bacteria showed maximum resistance to third generation Cephalosporins. The resistance to antimicrobials in particular to gram negative bacteria is of grave concern and measures to counteract this menace needs to be in place urgently. The findings in our study will help the clinicians to formulate proper empirical therapy for management of patients with bloodstream infections.
\end{abstract}

\section{Introduction}

Bloodstream infection (BSI), caused by bacteria or fungal pathogen, can be either community acquired or hospital acquired and lead to high mortality rates worldwide. Microorganisms gaining access to the bloodstream and causes target organ damage, which may lead to high magnitude of host reactions leading to sepsis and shock. Significant morbidity and mortality due to sepsis results from a systemic inflammatory response to the microbial insult, is a life threatening condition. Any delay in starting 
effective antimicrobial therapy in a patient with septicemia leads to poor prognosis and outcome in the patient \& may lead to loss of life. Initiation of proper and effective antimicrobial agent within the first hour of sepsis was seen to be associated $79.9 \%$ survival to hospital discharge.

At present the gold standard for diagnosis of bloodstream infection is blood culture by conventional or automated methods. In this method there is automated continuous or intermittent manipulation in conventional method of the blood culture bottles till positivity, which is followed by gram stain \& subcultures \& use of standard microbiological procedures to find out the pathogen \&their susceptibility to antimicrobials. The main disadvantage of existing blood culture system is the delay in completing the entire process of identification\& susceptibility testing. The delay may range from 1 to 5 days or more. Though the discovery \& application of reliable rapid diagnostic techniques for detection of pathogens causing bacterial blood stream infection (bBSI) is the need of the hour to manage these critical patients, however effective tests in this regard is yet to be developed for routine use. Molecular methodology, though are promising and can detect a range of pathogens and some their resistance mechanisms, but they are yet to guide which antimicrobials to be given to the sick.

Resultantly, the guide to appropriate antimicrobial therapy in patients with blood stream infections depends on blood culture reports. But as blood culture reports are available after a considerable time has lapsed after initial presentation or the appearance of symptoms, the clinician has to depend on initial empirical therapy with the antibiotics to which his clinical judgement guides. It was also seen in study by Kumar A et al., that inappropriate initial antimicrobial therapy for sepsis patients occurs in about $20 \%$ cases and is associate with five fold reduction in survival. Various studies reported changing resistance patterns of pathogens causing bloodstream infections in India \& worldwide. A proper understanding of infecting organisms each geographical area and their susceptibility pattern are crucial for selection of correct empirical antimicrobial therapy. This retrospective study is aimed to investigate the frequency of bacterial pathogens causing septicaemia and their antimicrobial susceptibility pattern in patients attending tertiary care super speciality institute of Northern India.

\section{Materials and Methods}

This was a retrospective observational hospital based study carried out over two years period from January 2015 to December 2016 at department of Microbiology, Dr Ram Manohar Lohia Institute of Medical Sciences, Lucknow. A total of 3485 blood culture samples processed during these two years were retrospectively evaluated, out of which 1707 samples were processed in 2016 \& 1778 samples were processed in 2015. Blood culture samples were routinely collected using standard precautions from patients presenting to the OPD \& admitted in wards/ ICU with clinical suspicion of bacteraemia, in aerobic \& anaerobic vials of automated VersaTrek blood culture system. The samples yielding positive growth would be further biochemically analysed to identify the pathogen \& their antimicrobial susceptibility according to the standard microbiological procedures \& using latest Clinical and Laboratory Standards Institute (CLSI) guidelines. Among the positive blood cultures with multidrug resistance pattern, the resistance mechanism like Extended spectrum $\beta$ lactamase(ESBL) producers, metallo- $\beta$-lactamase (MBL) producers, Methicillin resistant Staphylococcus aureus (MRSA), AmpC, High 
Level Aminoglycoside Resistance (HLAR) microorganisms will be detected. Skin pathogens if detected once would be considered as contaminant, however if they are isolated on repeated subcultured it would be considered as pathogen. Analysis of the microorganisms detected and their resistance pattern will be done using appropriate statistical tool.

\section{Results and Discussion}

During the study period of two years (January 2015 to December 2016) a total of 3485 blood culture samples were received in this tertiary healthcare centre, Lucknow. All clinically suspected patients whether hospitalised or OPD of bacteraemia were included in the present study. The mean blood culture positivity rate was $583 / 3485(16.73 \%)$ during these two years. The culture positivity in the year 2015 and 2016 were found to be 268/1707 (15.7\%) and 315/1778 (17.71\%) respectively.

\section{Distribution Profile of Blood borne bacterial isolates}

Amongst the isolated bacterial pathogens gram positive cocci were the predominant ones, 146 and 161 isolates in 2015 and 2016 respectively. Amongst the gram positive cocci, Coagulase Negative Staphylococci (CONS) was the most frequently isolated blood borne bacterial pathogen accounting for $37.69 \%$ \& $38.73 \%$ in the year $2015 \& 2016$ respectively, followed by Staphylococcus aureus (8.95\% in 2015 and $7.62 \%$ in 2016).

In the present study, $122(45.5 \%)$ and 154 $(48.9 \%)$ isolates of gram negative bacilli were identified on blood culture during 2015 and 2016 respectively. The cumulative percentage of gram negative pathogens isolated during two years were Eschrichia coli (12\%), Acinetobacter spp. (11.8\%), Pseudomonas spp
(5.7\%), Enterobacter spp (5.1\%), Klebsiella spp (4.3\%)and Citrobacter spp (3.4\%) as shown in figure 1 . In this study, we did not found any statistical significance between the gram positive and gram negative organisms in causation of blood stream infection.

\section{Antimicrobial Susceptibility Profile of Gram Positive isolates}

Among the total Gram positive cocci isolates, maximum resistance percentage was observed for Enterococcus spp followed by CONS and least in Staphylococcus aureus. The antibiotics to which the isolates were mostly resistant in the year 2015 and progressive rise in 2016 were mainly seen in Penicillin $(80.53 \%$-> 83.85\%), High level gentamicin resitance (77.27\% -> 93.7\%), Ciprofloxacin $(57.34 \%$-> $78.14 \%)$, Erythromycin (58.82\% ->74.82\%) and Levofloxacin $(37.5 \% \quad->67.32 \%)$ respectively. In this study, Enterococcus spp showed a rise in resistance towards linezolid (3.42\% to $7.94 \%)$ and teicoplanin $(0.65 \%$ to $3.31 \%$ ) drugs during 2015 and 2016; however, for vancomycin there was a slight decrease in the percentage of resistant isolates $(3.62 \%$ to $3.18 \%$ ) as analysed in figure 3 and table 8 .

In the present study, the ICU blood culture samples which came positive for gram positive bacterial pathogens were found to have higher antimicrobial resistance percentage mainly in Enterococcus spp followed by Staphylococcus aureus. Antimicrobials showed a surge in resistance pattern when compared during the year 2015 and 2016, drugs in which rise in resistance observed were Ciprofloxacin $(77.7 \%$ $>98.5 \%)$ Clindamycin (73.91->85.1\%), Erythromycin (73.07->96.07\%), Levofloxacin $(60 \%->89.85 \%)$, Tetracyclin $(12.5 \% \quad->$ $39.93 \%$ ), however there was a slight decrease in Penicillin resistance which was not statistically significant $(96 \%->94.44 \%)$ as shown in table 5. 


\section{Antimicrobial Susceptibility Profile of Gram Positive isolates}

As indicated in table 2 and 4, many gram negative bacilli which were isolated from blood stream found to be resistance. It was observed that there is a rise in drug resistance in the organisms from 2015 to 2016. On Analysing the susceptibility pattern of various antimicrobials, it was found that third generation cephalosporins $(79.78 \%$-> 87.3\%), ampicillin sulbactam $(69.23 \%$-> 84.87\%) and Aztreonam (81.33\% $\rightarrow \quad 89.58 \%)$ were predominantly resistant by most gram negative pathogens. In few antimicrobials there was presence of moderate resistance like piperacillin-tazobactam $(60.65 \%$-> 57.82\%), imipenem $(56.77 \% \rightarrow 63.41 \%)$, amikacin $(44.31 \%$-> 61.8\%) and levofloxacin $(52.63 \%$ $\rightarrow 71.1 \%)$.

In this study we reported a progressive escalation for antimicrobial resistance among the patients admitted in ICU in 2015 and 2016. Antimicrobials like third generation cephalosporins $(85.34 \% \rightarrow 93.51 \%)$, Ampicillin + Sulbactum (75\% -> 83.85\%), Imipenem (66 -> 72.22\%), Levofloxacin (77.77\% -> 83.52\%) and Amikacin (59.25\% $>73.7 \%$ ) were found to have immense resistance in gram negative pathogens as shown in table 10 .

Septicemia remains a significant cause of morbidity and mortality in the hospitalised patients and more so in those who are admitted in intensive care units. The clinical diagnosis of septicemia is difficult as it presents with non-specific signs and symptoms. The correct and timely identification of infectious agents and their antibiotic sensitivity patterns are essential to guide the clinicians regarding both the empirical and definitive treatment. In the present study, analysis of bloodstream infection was done during the study period of two years (January 2015 to December 2016), a total of 3485 blood culture samples were received from clinically suspected patients of bacteraemia in Out-patient and In-patient departments in the tertiary healthcare centre, Lucknow.

Among the total sample received for blood culture, the mean blood culture positivity rate was 583/3485 (16.73\%) during these two years. The culture positivity in the year 2015 and 2016 were found to be 268/1707 (15.7\%) and slightly elevated 315/1778 (17.71\%) respectively. Such observation did not reveal any significant difference of bloodstream infection rise in 2015 to 2016. The range of positive yield in blood culture varies from $1.2 \%$ to $42 \%$ depending on the geographical region, patient's age, patient's health condition, hospital bed capacity and proper follow up of antibiotic stewardship. The positivity rate in our study was consistent with the studies of Karunakaran et al., (16.7\%) and Santawana et al., (12.6\%) (Karunakaran et al., 2007; Santwana Pandey et al., 2013). In contrast to the rates which have been mentioned above, studies which were conducted in Mangalore, Delhi and Pakistan showed markedly higher rates (of more than $20 \%$ ), in the study of Viswanathan et al., from Kolkata yielded positivity rate of $46.3 \%$ respectively (Mehta et al., 2005; Chaudhry et al., 2000; Latif et al., 2009; Viswanathan et al., 2012).

In the present study analysis it was observed that gram positive cocci were the predominant ones amongst the isolated bacterial pathogens, 146 and 161 isolates in 2015 and 2016 respectively. Amongst the gram positive cocci, Coagulase Negative Staphylococci (CONS) was the most frequently isolated blood borne bacterial pathogen accounting for $37.69 \%$ \& $38.73 \%$ in the year 2015 \& 2016 respectively, followed by Staphylococcus aureus (8.95\% in 2015 and $7.62 \%$ in 2016). 
Table.1 Distribution of various organisms isolated in 2015 \& 2016

\begin{tabular}{|l|l|l|}
\hline \multirow{2}{*}{ Organisms } & Number of isolates (Percentage) \\
\hline CoNS & 2015 & 2016 \\
\hline Escherichia coli & $101(37.69 \%)$ & $122(38.73 \%)$ \\
\hline Acinetobacterspp & $31(11.57 \%)$ & $41(13.02 \%)$ \\
\hline Staphylococcus aureus & $30(11.19 \%)$ & $39(12.38 \%)$ \\
\hline Enterococcus spp & $24(8.95 \%)$ & $24(7.62 \%)$ \\
\hline Citrobacter spp. & $18(6.71 \%)$ & $16(5.1 \%)$ \\
\hline Enterobacter spp & $14(5.24 \%)$ & $7(2.2 \%)$ \\
\hline Pseudomonas spp & $13(4.85 \%)$ & $17(5.39 \%)$ \\
\hline Klebsiella spp & $10(3.73 \%)$ & $23(7.3 \%)$ \\
\hline Others & $6(2.24 \%)$ & $19(6.03 \%)$ \\
\hline
\end{tabular}

Fig/table.2 Gram Negative Isolate Resistance Percentage 2015 \&2016

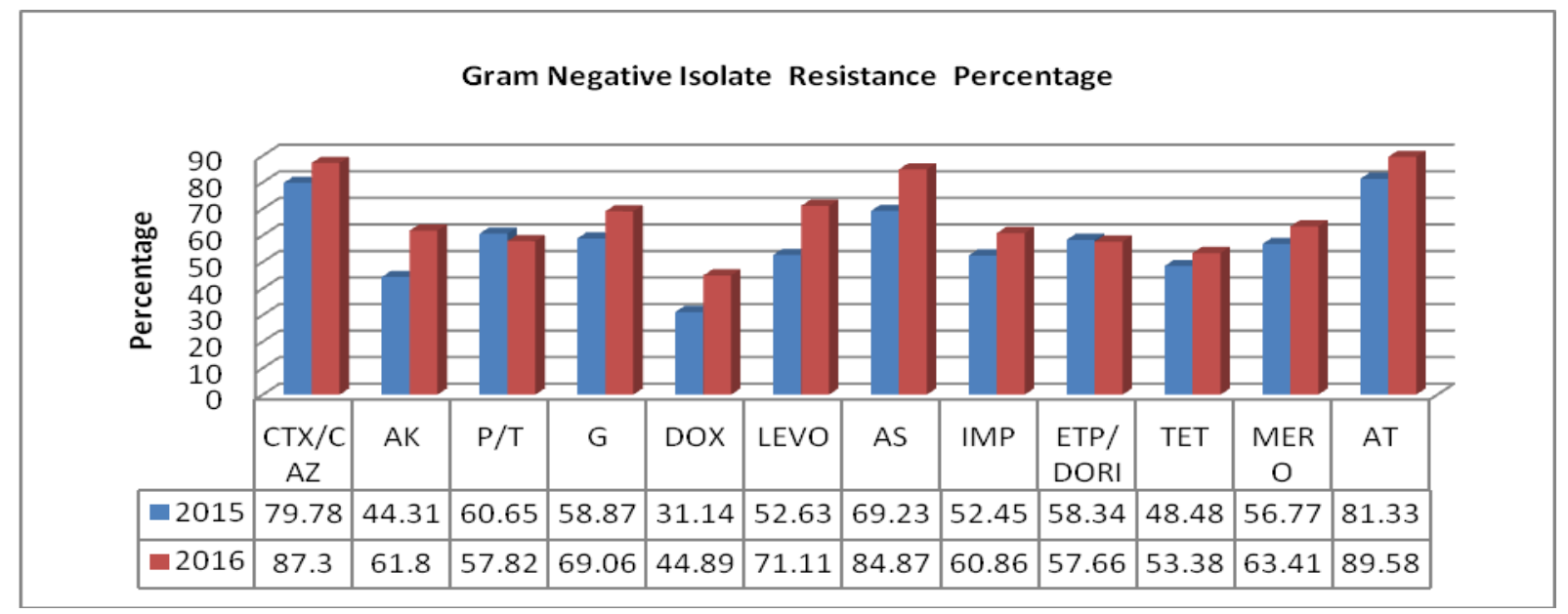

Fig/table.3 Gram Positive Isolate Resistance Percentage in 2015 \&2016

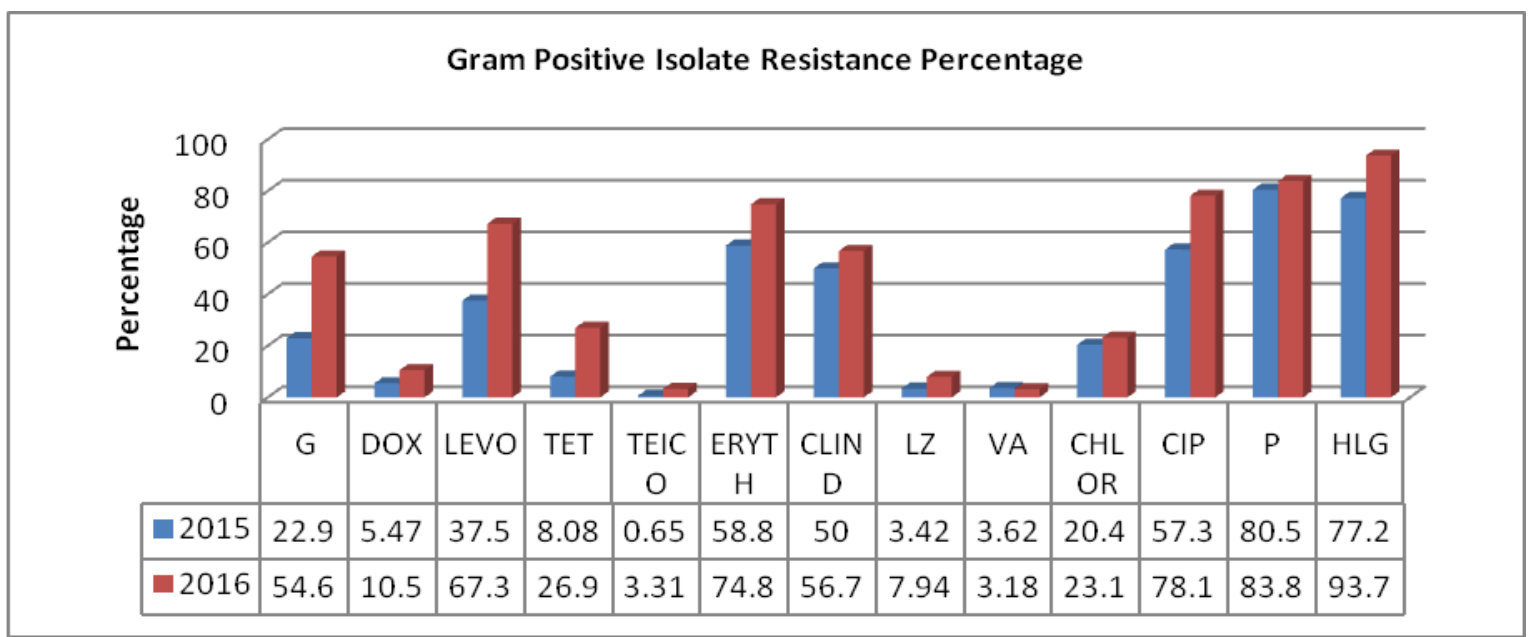


Fig/table.4 Gram Negative Isolate Resistance Percentage (ICU)

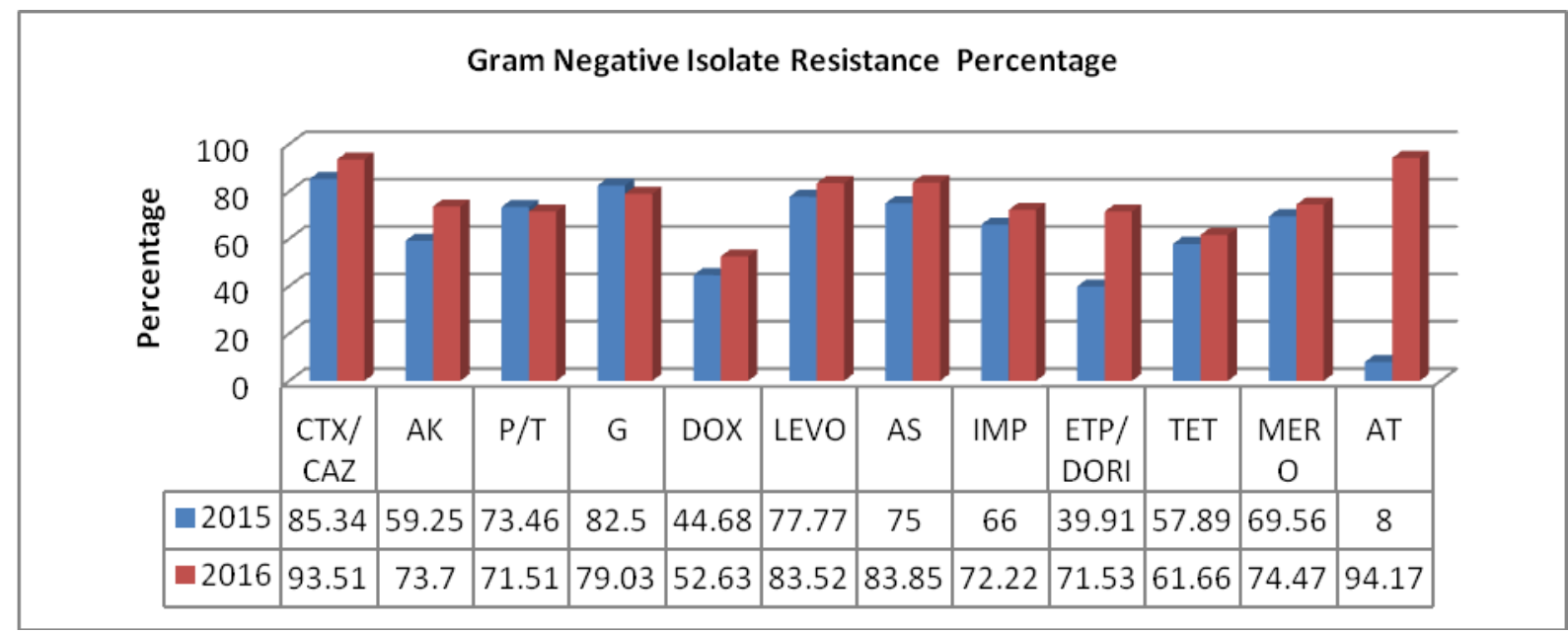

Fig/table.5 Gram positive Isolate Resistance Percentage (ICU)

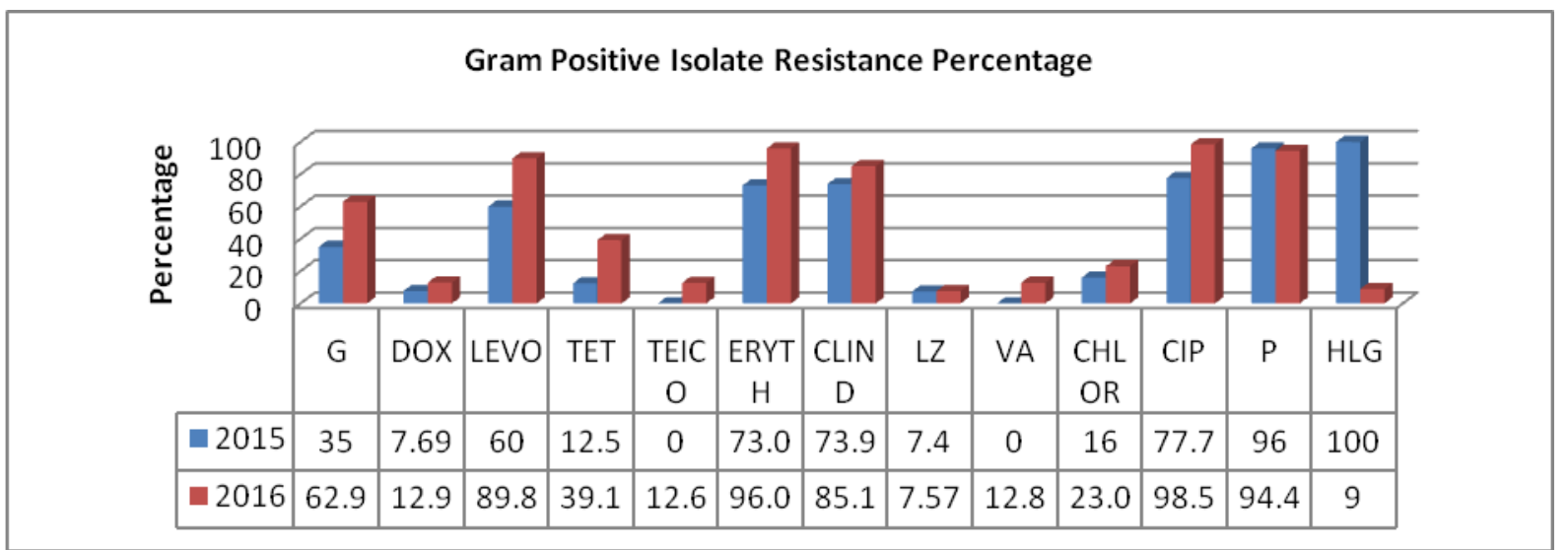

Table/fig.6 Resistance pattern for overall gram negative isolates in 2015

\begin{tabular}{|l|c|c|c|c|c|c|c|c|c|c|}
\hline $\begin{array}{l}\text { 2015 } \\
\text { Organism } \\
\text { (N) }\end{array}$ & $\begin{array}{l}\text { CTX/ } \\
\text { CAZ }\end{array}$ & P/T & G & DOX & LEVO & CIPRO & AS & IMP & TET & MIERO \\
\hline $\begin{array}{l}\text { Escherichia } \\
\text { coli(31) }\end{array}$ & 92 & 53.33 & 48.15 & 45.16 & 68 & 80 & 67.86 & 26.66 & 56 & 63.33 \\
\hline $\begin{array}{l}\text { Acinetobacter } \\
\text { spp.(30) }\end{array}$ & 83.33 & 68.96 & 64 & 40 & 44 & 60.71 & 59.26 & 78.57 & 54.54 & 54.54 \\
\hline $\begin{array}{l}\text { Citrobacter } \\
\text { spp. (14) }\end{array}$ & 83.33 & 66.66 & 72.72 & 30.77 & 63.63 & 81.81 & 81.81 & 66.67 & 63.63 & 81.81 \\
\hline $\begin{array}{l}\text { Enterobacter } \\
\text { spp.(11) }\end{array}$ & 72.72 & 72.72 & 66.67 & 9.10 & 60 & 66.66 & 87.5 & 54.54 & 20 & 72.72 \\
\hline $\begin{array}{l}\text { Pseudomonas } \\
\text { spp.(11) }\end{array}$ & 33.33 & 0 & 14.29 & --- & 16.67 & 14.29 & --- & 28.57 & --- & 28.57 \\
\hline
\end{tabular}


Int.J.Curr.Microbiol.App.Sci (2018) 7(6): 2446-2456

Table/fig.7 Resistance pattern for overall gram negative isolates in 2016

\begin{tabular}{|l|c|c|c|c|c|c|c|c|c|c|}
\hline $\begin{array}{l}\text { 2016 } \\
\text { Organism }\end{array}$ & $\begin{array}{c}\text { CTX/ } \\
\text { CAZ }\end{array}$ & P/T & G & DOX & LEVO & CIPRO & AS & IMP & TET & MERO \\
\hline $\begin{array}{l}\text { Escherichia } \\
\text { coli (41) }\end{array}$ & 95.12 & 64.10 & 65 & 45.45 & 94.59 & 94.74 & 86.49 & 57.89 & 65.71 & 59.46 \\
\hline $\begin{array}{l}\text { Acinetobacter } \\
\text { spp. (39) }\end{array}$ & 86.11 & 64.86 & 86.11 & 38.46 & 64.7 & 58.97 & 76.47 & 77.77 & 52.77 & 64.70 \\
\hline $\begin{array}{l}\text { Citrobacter } \\
\text { spp. (7) }\end{array}$ & 28.57 & 71.42 & 50 & 14.28 & 57.14 & 66.66 & 100 & 100 & 28.57 & 100 \\
\hline $\begin{array}{l}\text { Enterobacter } \\
\text { spp. (17) }\end{array}$ & 80 & 58.82 & 53.33 & 63.64 & 56.25 & 73.33 & 78.57 & 53.86 & 38.46 & 50 \\
\hline $\begin{array}{l}\text { Pseudomonas } \\
\text { spp. (23) }\end{array}$ & 40.9 & 34.78 & 52.63 & --- & 47.06 & 42.86 & --- & 54.54 & ---- & 50 \\
\hline
\end{tabular}

Table/fig.8 Resistance pattern for overall gram positive isolates in 2015

\begin{tabular}{|l|l|l|l|l|l|l|l|l|l|l|}
\hline $\begin{array}{l}2015 \\
\text { ORGANISM }\end{array}$ & G/HILG & DO & LE & CIPRO & TET & E & CD & LZ & C & VA \\
\hline $\begin{array}{l}\text { CoNS(101) } \\
\text { Enterococcus } \\
\text { spp.(18) }\end{array}$ & 61.11 & 4.17 & 29.35 & 52.13 & 7.69 & 54.35 & 51.55 & 3.19 & 22.98 & 1.11 \\
\hline $\begin{array}{l}\text { S.aureus (24) } \\
\text { 2. } 22.73\end{array}$ & 14.29 & 30.43 & 59.1 & 14.28 & 52.63 & 41.66 & 8.69 & 17.39 & 0 \\
\hline
\end{tabular}

Table/fig.9 Resistance pattern for overall gram positive isolates in 2016

\begin{tabular}{|l|l|l|l|l|l|l|l|l|l|l|}
\hline $\begin{array}{l}2016 \\
\text { ORGANISM }\end{array}$ & G/HILG & DO & LE & CIPRO & TET & E & CD & LZ & C & VA \\
\hline CoNS (121) & 52.17 & 10.75 & 62.83 & 75.89 & 22.32 & 74.28 & 53.51 & 9.71 & 24.04 & 1.72 \\
\hline $\begin{array}{l}\text { Enterococcus } \\
\text { spp. (16) }\end{array}$ & 93.75 & 15.38 & 93.8 & 93.75 & 63 & 100 & -- & 0.06 & 0.25 & 0.12 \\
\hline S.aureus (24) & 65.2 & 0 & 72.7 & 77.3 & 19 & 66.7 & 66.7 & 0.04 & 0.14 & 0 \\
\hline
\end{tabular}

Table/fig.10 Resistance pattern for gram negative isolates in 2015 in ICU

\begin{tabular}{|c|c|c|c|c|c|c|c|c|c|c|}
\hline $\begin{array}{l}2015 \text { ICU } \\
\text { Organism }\end{array}$ & $\begin{array}{l}\text { CTX/CA } \\
\mathrm{Z}\end{array}$ & $\mathbf{P} / \mathbf{T}$ & G & $\begin{array}{l}\text { DO } \\
\mathbf{X}\end{array}$ & $\begin{array}{l}\text { LEV } \\
0\end{array}$ & $\begin{array}{l}\text { CIPR } \\
\text { O }\end{array}$ & AS & IMP & TET & $\begin{array}{l}\text { MER } \\
\text { O }\end{array}$ \\
\hline $\begin{array}{l}\text { Escherichia } \\
\text { coli (12) }\end{array}$ & 100 & 90 & 100 & 50 & 91.7 & 100 & 90 & 50 & 50 & 66.67 \\
\hline $\begin{array}{l}\text { Acinetobacte } \\
\text { r spp.(19) }\end{array}$ & 94.74 & $\begin{array}{l}83.3 \\
3\end{array}$ & $\begin{array}{l}81.2 \\
5\end{array}$ & $\begin{array}{l}47.3 \\
7\end{array}$ & 68.75 & 77.77 & $\begin{array}{l}64.7 \\
1\end{array}$ & $\begin{array}{l}94.4 \\
4\end{array}$ & $\begin{array}{l}69.2 \\
3\end{array}$ & 75 \\
\hline $\begin{array}{l}\text { Citrobacter } \\
\text { spp.(7) } \\
\end{array}$ & 100 & $\begin{array}{l}26.6 \\
6\end{array}$ & 100 & $\begin{array}{l}33.3 \\
3\end{array}$ & 83.33 & 100 & 75 & $\begin{array}{l}83.3 \\
3\end{array}$ & 100 & 100 \\
\hline $\begin{array}{l}\text { Enterobacter } \\
\text { spp.(3) }\end{array}$ & 66.67 & $\begin{array}{l}66.6 \\
7\end{array}$ & $\begin{array}{l}66.6 \\
7\end{array}$ & $\begin{array}{l}33.3 \\
3\end{array}$ & 100 & 100 & $\begin{array}{l}66.6 \\
7\end{array}$ & $\begin{array}{l}33.3 \\
3\end{array}$ & $\begin{array}{l}33.3 \\
3\end{array}$ & 66.67 \\
\hline $\begin{array}{l}\text { Pseudomonas } \\
\text { spp.(7) }\end{array}$ & 50 & 0 & $\begin{array}{l}33.3 \\
3\end{array}$ & ---- & 50 & 20 & -- & 20 & --- & 33.33 \\
\hline
\end{tabular}


Table/fig.11 Resistance pattern for gram negative isolates in 2016 in ICU

\begin{tabular}{|l|l|l|l|l|l|l|l|l|l|l|}
\hline $\begin{array}{l}2016 \quad \text { ICU } \\
\text { Organism }\end{array}$ & $\begin{array}{l}\text { CTX/ } \\
\text { CAZ }\end{array}$ & P/T & G & DOX & LEVO & CIPRO & AS & IMIP & TET & MIERO \\
\hline $\begin{array}{l}\text { Escherichia } \\
\text { coli (14) }\end{array}$ & 100 & 64.3 & 71.4 & 50.0 & 85.7 & 92.85 & 91.7 & 71.4 & 58.4 & 76.92 \\
\hline $\begin{array}{l}\text { A cinetobacter } \\
\text { spp.(27) }\end{array}$ & 85.2 & 61.5 & 80.8 & 42 & 68 & 68 & 75 & 73 & 48 & 60.87 \\
\hline $\begin{array}{l}\text { Citrobacter } \\
\text { spp. (7) }\end{array}$ & 66.66 & 71.4 & 50 & 14.3 & 57.2 & 66.66 & 100 & 57.2 & 28.6 & 100 \\
\hline $\begin{array}{l}\text { Enterobacter } \\
\text { spp.(11) }\end{array}$ & 100 & 63.6 & 60 & 87.5 & 63.6 & 88.9 & 100 & 55.6 & 71.4 & 42.9 \\
\hline $\begin{array}{l}\text { Pseudomonas } \\
\text { spp.(11) }\end{array}$ & 50 & 63.3 & 77.8 & --- & 85.3 & 72.73 & ---- & 10 & --- & 66.66 \\
\hline
\end{tabular}

Table/fig.12 Resistance pattern for gram positive isolates in 2015 in ICU

\begin{tabular}{|l|l|l|l|l|l|l|l|l|l|l|}
\hline $\begin{array}{l}2015 \\
\text { ICUORGANISM }\end{array}$ & G/HLG & DO & LE & CIPRO & TET & E & CD & LZ & C & VA \\
\hline CoNS (18) & 33.33 & 0 & 52.94 & 77.78 & 5.88 & 58.82 & 66.66 & 5.55 & 12.5 & 0 \\
\hline $\begin{array}{l}\text { Enterococcus } \\
\text { spp. (4) }\end{array}$ & 100 & 0 & 100 & 100 & 0 & 100 & --- & 0 & 0 & 0 \\
\hline \begin{tabular}{l} 
S.aureus (5) \\
\hline
\end{tabular} & 40 & 40 & 50 & 100 & 40 & 100 & 100 & 20 & 40 & 0 \\
\hline
\end{tabular}

Table/fig.13 Resistance pattern for gram positive isolates in 2016 in ICU

\begin{tabular}{|l|l|l|l|l|l|l|l|l|l|l|}
\hline $\begin{array}{l}2016 \quad \text { ICU } \\
\text { ORGANISM }\end{array}$ & G/HLG & DO & LE & CIPRO & TET & E & CD & LZ & C & VA \\
\hline CoNS(26) & 58 & 4.4 & 78.3 & 95.6 & 4.4 & 0 & 78.3 & 0 & 48 & 0 \\
\hline $\begin{array}{l}\text { Enterococcus } \\
\text { spp.(5) }\end{array}$ & 80 & 20 & 0 & 100 & 20 & 75 & --- & 0 & 20 & 0 \\
\hline \begin{tabular}{l} 
S.aureus (6) \\
\hline
\end{tabular} & 83.3 & 0 & 83.3 & 100 & 0 & 0 & 83.3 & 0 & 20 & 0 \\
\hline
\end{tabular}

Novel therapeutic interventions and increased use of foreign medical devices have been paralleled by the emergence of CoNS as formidable pathogens in health- care settings. Garg et al., have reported a higher incidence of CONS which is about $20.7 \%$ and much lower incidence of Staphylococcus aureus which was about $8.3 \%$ (Garg and Garg, 2017). These findings in our study for gram positive bacterial pathogens was also consistent with the reports of Ashtiani et al., from Iran and Karunakaran et al., from
Malaysia (Karunakaran et al., 2007; Haghi Ashtiani et al., 2013). However, Most Western literature and few Indian studies suggests that CoNS account for $25 \%-57 \%$ of the cases of BSI, clinical significance of the CoNS isolated was not defined in these studies and may have resulted in an overestimation of prevalence. The colonisation of the skin and nasopharynx by CONS and S. aureus in health care workers, overcrowding in ICU, and improper hand washing techniques may lead to transmission 
of Gram-positive organisms in patients horizontally. There is a multifactorial cause for this difference between western and Indian literature, perhaps due to variations in the use of invasive medical devices, ambient humidity, prevalent flora in the hospital environment or on the health- care workers and patients. All CoNS isolates were susceptible to vancomycin, teicoplanin, linezolid and netilmicin. A study which was done by Mehdinejad $\mathrm{M}$ et al., also reported cent percent sensitivity for Vancomycin (Mehdinejad et al., 2009). These drugs may be included in therapy for patients with MRCoNS infections; however, empirical use must be avoided before recording results of susceptibility tests as overuse of these antibiotics can promote glycopeptide and oxazolidinone resistance. Among the total Gram positive cocci isolates, maximum resistance percentage was observed for Enterococcus spp followed by CONS and least in Staphylococcus aureus. The antibiotics to which the isolates were mostly resistant in the year 2015 and progressive rise in 2016 include penicillin, fluoroquinolones, aminoglycosides and macrolide antibiotics. In Enterococcus spp, 3-7\% isolates were found to have resistance against linezolid and 1-3\% against teicoplanin. The findings of antimicrobial susceptibility among gram positive bacterial pathogens were consistent with the reports of Ashtiani et al., from Iran (Haghi Ashtiani et al., 2013). In this study, the incidence of MRSA in $S$. aureus strains was high. The occurrence of MRSA is more common because of indiscriminate use of higher antibiotics as an emergency empirical therapy. Vancomycin remains the drug of choice for the Gram positive bacterial isolates like MRSA and HLAR in our setup.

In the present study, $122(45.5 \%)$ and 154 $(48.9 \%)$ isolates of gram negative bacilli were identified on blood culture during 2015 and 2016 respectively. The cumulative percentage of gram negative pathogens isolated during two years were Eschrichia coli (12\%) and non-fermenting gram negative pathogens like Acinetobacter spp. (11.8\%) and Pseudomonas spp $(5.7 \%)$. Beta-lactam were the most widely used antibiotics against Gram negative bacteria. In our study, resistance to third generation cephalosporins implied extended spectrum beta lactamases (ESBL) production in Escherichia coli and Klebsiella pneumoniae. Hence, beta-lactamases activity produced by Gram- negative bacteria may be the possibility of resistance to cephalosporins studied. E. coli and other Enterobacteriaceae were predominantly resistant to all commonly available first line antibiotics like cefotaxime, ampicillin, and ciprofloxacin and gentamicin. Organisms belonging to family enterobacteriaceae also showed considerable resistance rates for reserve antibiotics (e.g. piperacillin-tazobactam, cefoperazone sulbactam, amikacin). Gram-negative isolates showed a high resistance to all cephalosporins which is similar to the resistance pattern reported by Agnihotri et al., (2004). In the present study we also observed increase resistance in carbapenem group of drugs like meropenem and imipenem which reached upto $60-70 \%$ isolates of gram negative pathogens. The resistance was escalated in immunocompromised patients admitted in intensive care units. Bloodstream infections have serious consequences like shock, disseminated intravascular coagulation, multiple organ failure, and even death. Increased hospital stay and associated costs are the most troublesome consequences.

Blood culture is the gold standard in diagnosis and treatment of septicemia. Multiple antibiotic resistances among sepsis are currently one of the greatest challenges to the effective management of infections. Slow race in development of newer drugs and rapidity in resistance development are major areas of concern. Antibiotic stewardship 
should be done in all the hospitals or there will be no drugs available in the future for treatment.

\section{References}

Agnihotri N, Kaistha N, Gupta V. Antimicrobial susceptibility of isolates from neonatal septicemia. Jpn J Infect Dis. 2004; 57: 273-275.

Angus, D.C., and T. Van der Poll, "Severe sepsis and septic shock," The New England Journal of Medicine, vol. 369, no. 9,pp. 840-851, 2013.]

Chaudhry I, Chaudhry NA, Munir M, Hussain R, Tayyab M. Etiological Pattern of septicemia at Three Hospitals in Lahore. JCPSP. 2000; 10: 375-79.

Garg SK, and Garg P. Polymicrobial blood stream infection: Consensus definition is required. Indian $\mathrm{J}$ Crit Care Med 2017; 21: 712-3

Haghi Ashtiani MT, Mamishi S, Masoomi A, Nasiri N, Hosseini M, Nikmanesh B, Pourakbari B, Rezaei N. Braz J Infect Dis. 2013 Jul-Aug; 17(4): 497-9.

Jean Pierre Rutanga and Therese Nyirahabimana. Clinical Significance of Molecular Diagnostic Tools for Bacterial Bloodstream Infections: A Systematic Review. Interdiscip Perspect Infect Dis. 2016; 2016: 6412085.

Karunakaran, R., Raja, N., Ng, K. and Navaratnam, P. (2007) Etiology of blood culture isolates among patients in a multidisciplinary teaching hospital in Kuala Lumpur. J Microbiol Immunol Infect 40: 432-437

Kumar A, Roberts D, Wood KE, Light B, Parrillo JE, Sharma S, et al., Duration of hypotension before initiation of effective antimicrobial therapy is the critical determinant of survival in human septic shock. Crit Care Med2006; 34: 1589-96.].
Kumar, A., P. Ellis, Y. Arabi et al., "Initiation of inappropriate antimicrobial therapy results in a fivefold reduction of survival in human septic shock," Chest, vol. 136, no. 5, pp. 1237-1248, 2009

Latif S, Anwar MS, Ahmad I. Bacterial pathogens responsible for blood stream infection (BSI) and pattern of drug resistance in tertiary care hospital in Lahore. Biomedia. 2009; 25: 101-105.

Loonen, A. J. M., P. F. G. Wolffs, C. A. Bruggeman, and A. J.C. van den Brule, "Developments for improved diagnosis of bacterial bloodstream infections," European Journal of Clinical Microbiology and Infectious Diseases, vol. 33, no. 10, pp. 1687-1702, 2014

Mehdinejad, M., A. D. Khosravi, and A. Morvaridi, "Study of prevalence and antimicrobial susceptibility pattern of bacteria isolated from blood cultures," Journal of Biological Sciences, vol. 9, no. 3, pp. 249-253, 2009.

Mehta M, Dutta P, Gupta V. Antimicrobial susceptibility pattern of blood isolates from a teaching hospital in north India. Jpn J Infect Dis. 2005; 58: 174-76.

Santwana Pandey, Shahid Raza, and Chandra Prakash Bhatta, The Aetiology of the Bloodstream Infections in the Patients Who Presented to a Tertiary Care Teaching Hospital in Kathmandu, Nepal. J Clin Diagn Res, April 2013, 7(4): 638-641

Viswanathan R., Singh A., Ghosh C., Dasgupta S., Mukherjee S., Basu S. (2012) Profile of neonatal septicaemia at a district-level sick newborn care unit. J Health Popul Nutr 30: 41-48.

Wikler MA. Performance standards for antimicrobial disk susceptibility tests: approved standard. Clinical and Laboratory Standards Institute; 2016 


\section{How to cite this article:}

Manodeep Sen, Vikramjeet Singh, Gaurav Kumar, Rachana Kanaujia, Vineeta Mittal and Anupam Das. 2018. Antimicrobial Susceptibility Profile from Patients with Blood Stream Infections at a Tertiary Care Level Super Speciality Institute in Northern India. Int.J.Curr.Microbiol.App.Sci. 7(06): 2446-2456. doi: https://doi.org/10.20546/ijcmas.2018.706.291 